Özçakmak, H., ve Hakkoymaz, S. (2017). Üniversite birinci sınıf öğrencilerinin elektronik posta yazma becerilerinin değerlendirilmesi. Ana Dili Eğitimi Dergisi, 5(4), 985-997.

$\begin{gathered}\text { Ana Dili Eğitimi Dergisi } \\ \text { Journal of MotherTongueEducation } \\ \text { www.anadiliegitimi.com }\end{gathered}$
Geliş/Received: 15.09 .2017 Kabul/Accepted:15.10.2017

\title{
Üniversite Birinci Sınıf Öğrencilerinin Elektronik Posta Yazma Becerilerinin Değerlendirilmesi
}

\author{
Hüseyin ÖZÇAKMAK* \\ Sakine HAKKOYMAZ**
}

\begin{abstract}
Öz
Çalışmanın amacl; üniversite birinci sınıf öğrencilerinin elektronik posta yazma becerilerini belli kriterler altında incelemek ve e-posta yazma konusundaki öğrenci görüşlerini tespit etmektir. Araştırmada, nitel araştırma yöntemlerinden doküman incelemesi ve içerik analizi kullanılmıştır. Çalışmada, seçkisiz yöntemle belirlenen 50 e-posta incelenmiştir. Ayrıca 3 soruluk yapılandırıımış görüşme formu ile 24 öğrenciden görüş alınmıştır. Veriler, araştırmacılar tarafından geliştirilen EPosta Yazma Yeterliliği Envanteri ve yapılandırılmıs görüşme formu ile toplanmıştır. Araştırma sonucunda, öğrencilerin en fazla açıklamalı e-posta gönderme $(f=48)$, dili özenli kullanma ( $f=38$ ) ve adını soyadını yansıtan bir e-posta hesabı kullanmaya(f=25); en az ise, önemli e-postalara bayrak işareti koyma $(f=2)$, ekli e-posta gönderme $(f=2)$, cc ve bcc seçeneklerini kullanma $(f=0)$ konusuna dikkat ettikleri belirlenmiştir. Görüşme sorularının analizi sonucunda öğrencilerin en çok e-postayı kime göndereceğini belirleme $(f=11)$ ile yazım ve noktalama $(f=10)$ konusuna dikkat ettikleri; e-postayı en çok, iletişim kurma ( $f=13)$, dosya paylaşma $(f=7)$ ve ödev gönderme $(f=7)$ amacıyla kullandıkları tespit edilmiştir. E-posta iletişimi sırasında karşılaştıkları sorunların başında belgenin zamanında ulaşmaması ( $f=7)$, dosya boyutunun fazla gelmesi $(f=5)$ ve internet kesintisi $(f=4)$ gelmektedir. Sorun yaşamadıklarını ifade eden öğrencilerin sayısının ise 7 olduğu saptanmıştır.
\end{abstract}

Anahtar Kelimeler: e-posta, e -posta yazma yeterliliği, üniversite öğrencileri, öğrenci görüşleri

\section{Evaluation of Electronic Mail Writing Skills of Freshman Students}

\begin{abstract}
The purpose of the study was to examine the skills of electronic mail writing for freshman students under certain criteria and to identify student opinions on e-mail writing. In the research, document review and content analysis among qualitative research methods and techniques were used. Randomly selected 50 e-mails were examined in the study. In addition, 24 students were interviewed with a structured interview form consisted of 3 questions. The data were collected through the E-mail Writing Competence Inventory developed by the researchers and the structured interview form. As a result of the research, it was determined that the students paid most attention to sending e-mail with descriptions ( $f=48)$, using language attentively $(f=38)$ and using an e-mail account that reflects their name and surname $(f=25)$; and least attention to adding flag marks in important e-mails $(f=2)$, sending e-mail with attachments $(f=2)$, and using cc
\end{abstract}

*Yrd. Doç. Dr., Mustafa Kemal Üniversitesi, Eğitim Fakültesi, Türkçe ve Sosyal Bilimler Eğitimi Bölümü. Hatay. E-posta: h.ozcakmak@mku.edu.tr

** Öğr. Gör., Hasan Kalyoncu Üniversitesi, Eğitim Fakültesi, Temel Eğitim Bölümü. Gaziantep.

E-posta: sakine.hakkoymaz@hku.edu.tr 
and bcc options $(f=0)$. As a result of the analysis of the interview questions, the students paid most attention to determining to whom they sent the e-mail $(f=11)$, spelling and punctuation $(f=$ $10)$, and they used e-mails mostly for communication ( $f=13)$, sharing a file $(f=7)$ and homework submission $(f=7)$. The main problems encountered while writing an e-mail were late submission of the document $(f=7)$, too large file size $(f=5)$ and the internet outage $(f=4)$. It was determined that the number of students who expressed that they did not experience any problems was 7.

Keywords: e-mail, e-mail writing competence, university students, student opinions

\section{Giriş}

Teknoloji günümüzde oldukça yaygın kullanılmakta ve takip edilmektedir. Eğitimden sağlığa, ulaşımdan madenciliğe, tarımdan ekonomiye kadar her alanda teknoloji ve onun getirdiği yenilikleri görmekteyiz. Giderek dijitalleşen bir dünyada yaşıyoruz ve iletişim teknolojileri, insanoğlunun yaşamına hiç olmadığı kadar hâkim. Öyle ki, telefonunu evde unutan veya telefonunun şarjı biten bir kişi, tedirginlik yaşamakta, kendisini dünyadan izole olmuş gibi hissedebilmektedir.

2017 Ocak ayında WeAreSocialandHootsuite tarafından yayımlanan "Digital in 2017 Global Overview" adlı rapora göre, dünyada3,8 milyar Türkiye'de 48 milyon internet kullanıcısı bulunmaktadır (URL 1). 2000'li yıllarda Türkiye'de internete nüfusun \%3-4'ü erişebilirken (Bengshir, 2000) günümüzde bu oran \%60’a (48 milyon) ulaşmıştır. Kısa sayılabilecek bir sürede, internet kullanımın baş döndürücü bir şekilde artmış olması, önümüzdeki yıllarda, dijitalleşmenin insanları birçok konuda derinlemesine etkileyeceğini göstermesi bakımından önemlidir.

Gelişen teknolojiler, bilgi çağı olarak tanımlanan 21. yüzyılda, birçok alanda olduğu gibi, iletişim alanında da önemli değişiklikler meydana getirmiştir. İletişim alanında yaşanan gelişmelerin en önemli aktörü internet teknolojileridir. Kısa bir geçmişe sahip olmasına rağmeninternet, dünya üzerinde yaygın kullanım alanına erişmiştir. Ticaret, haberleşme, eğlence sektörü, eğitim ve hatta yönetim uygulamalarında bile interneti kullanmak mümkündür (Çakır ve Topçu, 2006).

Internet teknolojisinin sunduğu, dünya üzerindeki insanların birbirleriyle daha kolay iletişim kurmalarını sağlayan en yaygın hizmetlerden biri de e-postadır (Bradleyve Carvey, 2006: 86). Internetin yaygınlaşmasıyla birlikte, e-posta kullanımı da artmıştır. Son otuz yılda e-posta, yalnızca teknoloji uzmanları tarafından kullanılan bir uygulama olmaktan çıkarak genel nüfus tarafından da benimsenen ortak bir iletişim aracına dönüşmüştür (HuangveLin, 2014). Başlangıçta bir iletişim tercihi olan e-posta;iş başvurusu yapmak, internetten alışveriş yapmak, sitelere üye olmak, sosyal medya hesabı açmak gibi nedenlerlezorunlu hâle gelmiştir. Hatta günümüzde insanların, farklı sunuculardan eriştikleri birden çok e-posta hesabı bulunmaktadır. Özel işlerle diğer işleriayırmak, adını yansıtan daha ciddî bir e-postahesabı açmak ve daha fazla üyelik hakkı kazanmak, bu durumun sebepleri arasında sayılabilir. Ayrıca e-posta hizmeti sunucularının sağlamış oldukları hizmet kalitesi de (hız, dosya gönderme-alma boyutu vb.) kişilerin birden fazla e-posta hesabı oluşturmalarını tetiklemektedir. 
Ilk başlarda, e-posta hizmeti sunan belli başı şirketler varken, artık şirket ve üniversite gibi birçok yerel veya global kurum ve kuruluşun kendi kurumsal e-posta uzantıları bulunmaktadır.Başlangıçta askerî ve bilimsel kullanım için tasarlanmış olan e-posta, 1960'ı ve 70'li yıllarda, başka bir deyişle Soğuk Savaş'ın en yoğun olduğu dönemlerde Amerika'nın ulusal savunmasındaki gelişmeler neticesinde, elektronik mesajlaşma biçimi olarak ortaya çıkmış (Baron, 1998), dünya çapında yaygınlaşmıştır.

İstatistiklere göre dünyada 4 milyardan fazla e-posta hesabı bulunmaktadır. Bu e-posta hesaplarından her gün 200 milyar e-posta alınıp gönderilmektedir (Nawaz, KhanveLee, 2016). 1960'। yıllarda Amerikan Hükümetitarafından başlatılan ve akademik olarak geliştirilen e-postanın, kısa bir sürede şehirlerarası telefon görüşmelerine ve yüz yüze konuşmalara alternatif, uluslararası bir iletişim yöntemi (Baron,1998) olması son derece şaşırtıcıdır. E-posta ya da e-mail olarak adlandırılan bu teknoloji, aslında internet üzerinden gönderilen dijital mektuplardır. İletişim kurma amacı bakımından mektupla benzerlik gösteren elektronik posta; yazı, resim, müzik, video gibi her türlü dosya türünü dünyanın her yerine anlık olarak iletebilmesiyönüyle, mektuptan çok daha üstün bir konuma geçmiştir.

Literatürde e-posta ile ilgili birtakım tanımlamalar bulunmaktadır. Sözgelimi, Özbay ve Akyazı (2004: 4) tarafından yapılan tanıma göre e-posta; bir bilgisayardan diğerine/diğerlerine veya bir kişiden diğer kişiye/kişilere gönderilen elektronik mesajlardır. Elektronik posta,Türkçe Sözlük'te (Türk Dil Kurumu, 2011: 785) “bilgisayarlar veya bir ağ içindeki belli gönderim merkezleri arasında elektronik bilgi iletişimi, elmek, e-posta" şeklinde tanımlanmıştır. Sözlükte elektronik mektup kelimesinden türetilen elmek kelimesine de yer verilmiştir (TDK, 2011: 791).

E-postanın birçok avantajı vardır. Hızlı bir iletişime olanak sağlama, dünyanın neresinde olursa olsun, aynı anda birçok kişiye ulaşma, bireysel iletişim yönetimine imkân tanıma, çok çabuk dönüt sağlama, yazışmaların kaydedilmesine imkân verme ve basit bir kullanıma sahip olmabunlardan bazılarıdır (Munter, Rogers,veRymer, 2003; DabbaghveBannan-Ritland, 2005).Eposta, yukarıda sayılan avantajları nedeniyle,ticarîve akademik kurumlarda, kişisel ve kurumsal iletişim için yaygın olarak kullanılmaktadır (Chen, 2006).E-posta eğitime yardımcı bir araç olarak da kullanılmaktadır. Özellikle akademik dünyada, öğretim elemanları ve öğrenciler arasındaeş zamansızbir iletişim biçimi sağlaması yönüyle e-postaönemli bir işleve sahiptir(FilipponeveSurvinski, 2016).

Elektronik posta, kontrol bilgisi ve içerik olmak üzere iki ana bölümden meydana gelmektedir. Klasik bir postanın zarf kısmı, kontrol bilgisi bölümüne, mektup kısmı da içerik bölümüne benzetilebilir. Genel olarak, mesajın kime gideceği (to), mesajın konusu (subject), aynı mesajın 
gideceği diğer adres (carboncopy) gibi bilgiler kontrol bilgisi bölümünü oluşturmaktadır. Mesajın bulunduğu kısım ise içeriktir (Haşıloğlu, 1999: 53).

E-posta iletişiminde dikkat edilmesigereken birtakım hususlar vardır. Önceliklee-postaların doğru alıcı/alıcılara gönderilmesi konusunda hassas davranılmalı,gönderilen e-postalar kontrol edilerek içeriğinin tam ve hatasız olmasına itina gösterilmelidir. Aksi durumda, dikkatsiz davranan, işine gereken önemi vermeyen birisi olarak algılanabilir vebirtakım eleştirilere maruz kalabiliriz. Öte yandan gönderilen e-postaların, silinse bile, karşı tarafta kayıtı kalacağıakıldan çıkarılmamalıdır. Bu nedenle yazılan e-postaların kontrol edilmesi ve emin oluncaya kadar "kime" kısmının doldurulmaması gerekir. E-posta, iyice kontrol edildikten ve düzenlendikten sonra gönderilmelidir (Lamb, 2006).

Internetle iç içe yaşamaktayız ve çocuklar da bu durumdan paylarını almaktadırlar. Nitekim Aslan (2016) tarafından 9-16 yaş grubu Türk çocuklarının 2010-2015 yılları arasında internet kullanımlarını belirlemek amacıyla gerçekleştirilen bir araştırmada, çocukların internet kullanma yaşlarının giderek düştüğü, internet kullanım sürelerinin ise gittikçe yükseldiği belirlenmiştir.Internetin yaygınlaşmasıyla,öğrencilerin bilişim teknolojilerini daha etkili ve amacına uygun kullanmaları da önem kazanmıştır. Bu amaç doğrultusunda, Millî Eğitim Bakanlı̆̆ı (MEB) Talim ve Terbiye Kurulu tarafından 05.09.2012 tarihindealınan 150 sayılı kararla "Bilişim Teknolojileri ve Yazılım" dersi ortaokul5, 6, 7 ve 8. sınıflar için seçmeli ders olarak kabul edilmiştir (URL 2).Daha sonrasında ise kurulun 17.07.2017 tarihli 78 sayılı kararıyla, bu dersin ortaokul 5 ve 6 'ncı sınıflarda zorunlu, 7 ve 8'inci sınıflarda seçmeli ders olarak okutulması kararlaştırılmıştır (URL 3). 2017 yılında yayımlanan Bilişim Teknolojileri ve Yazılım Dersi Öğretim Programı'nda e-posta öğretimi konusu 5. sınıf seviyesinde ele alınarak "E-posta hesabı oluşturur ve iletişim kurmada kullanır." kazanımına yer verilmiştir (MEB, 2017: 19). İnternet kullanımının yaygınlaşmasıyla birlikte internetin sağladığı teknolojiden faydalanmakda ehemmiyet kazanmıştır. Bu sebeple, e-posta ve diğer bilişim teknolojilerinin ortaokuldan itibaren verilmesi, doğru bir yaklaşım olarak görünmektedir.

Yurtdışında bu konuda birçok çalışma yapılmıştır. Sözgelimi, Stockwell ve Levy tarafından (2001) gerçekleştirilen çalışmada, e-posta yazarken fazla sayıda mesaj üreten öğrencilerin daha başarılı oldukları, yüksek dil yeterliliğine sahip öğrencilerin düşük olanlara kıyasla e-posta yazma konusunda daha üretken oldukları saptanmıştır. Shang (2007) tarafından Tayvan'da İngilizce öğrenimi gören üniversite öğrencileri üzerinde gerçekleştirilen çalışmada ise öğrencilerin yazdıkları e-postalar incelenmiştir. Çalışmada,e-posta yazmanın, öğrencilerin yabancı dillerini geliştirmeye yardımcı olduğu; akranları ile en az dört kez e-posta alışverişi yapan öğrencilerin e-posta yazma performanslarında genel bir iyileşme olduğu ortaya konmuştur. 
Hani ve Alghonaim'ın (2014) yaptığı çalışmada, e-posta yoluyla diyalog kurulmasının İngilizceyi yabancı dil olarak öğrenen, zayıf yazma yeterliliğine sahip öğrencilerinyazma becerilerine etkisi araştırılmıştır. Çalışma, Ürdün'de üniversite birinci sınıfta okuyan $40 \mathrm{kız}$ öğrenci ile yürütülmüştür. Çalışmada daha önceden belirlenen materyal, deney grubunda e-posta yoluyla, kontrol grubunda ise geleneksel yöntemle (kalem-kâğıt kullanarak) çalışılmıştır. Sonuçta,e-posta yoluyla diyalog kurarakçalışan öğrencilerin kalem-kâğıt kullanarak çalışan öğrencilere göre daha iyi yazdıkları belirlenmiştir. Son olarak, Zarepour ve Saidloo (2016) tarafından yapılan çalışmada İngilizce öğrenen İranlı öğrencilerin e-posta yazma becerileri incelenmiştir. 61 e-postanın analiz edildiği çalışmada, İranlı öğrencilerin isteme, kabul etme, reddetme gibi doğrudan stratejileri daha fazla kullandıkları ancak e-posta metinlerinin, sosyal ve kültürel unsurları kapsayan pragmatik ögeler konusunda eksik olduğu tespit edilmiştir.

Türkiye'de ise e-posta konusunda yapılan çalışmalar oldukça sınırıdır. Literatürde, birkaç tez ve makale dışında (Gürkaya, 1999; Erkan, 2004; Güler, 2007; Eliçin, 2011; Erkan, 2013; Bayır, 2014) herhangi bir çalışmaya rastlanmamıştır. Bu çalışmalarda ise, internet ve elektronik postanın yazı derslerinde kullanımı (Gürkaya, 1999); İngilizce yazma becerisini geliştirmede elektronik posta (Erkan, 2004); uzaktan öğrenenlerin e-postayla etkileşime girme ve yüz yüze ortamlarda iletişime girme isteklilikleri arasındaki ilişki (Güler, 2007); yabancı dil öğrencilerinin rica ve özür dileme stratejileri (Eliçin, 2011); kültürlerarası elektronik posta yoluyla yazışmanın öğrencilerin yazma özyetkinliğini geliştirmeye etkisi (Erkan, 2013) ve çevrimiçi öğrenme ortamlarında sohbet ve e-posta kullanımının öğrencilerin işlemsel uzaklık algılarına etkisi (Bayır, 2014) konuları ele alınmıştır. Adı geçen çalışmalarda, e-posta yazma becerisi başka disiplinlerle birlikte ele alınmış, öğrencilerin e-posta yazma becerilerini tek başına irdeleyen ve e-posta konusunda ne düşündükleri araştıran çalışmalara rastlanmamıştır. Bu çalışmanın amacı,üniversitebirincisınıf öğrencilerinin elektronik postayazma yeterliliklerini belirlemek ve e-posta yazma konusundaki görüşlerini tespit etmektir.

\section{Yöntem}

\section{Araştırma Modeli}

Çalışma, betimsel tarama modelindedir. Çalışmadanitel araştırma yöntem ve teknikleri kullanılmıştır. Öğrencilerin öğretim elemanlarına göndermiş oldukları elektronik postalar doküman incelemesiyle;e-posta yazmaya dair öğrenci görüşleri ise içerik analiziyle irdelenmiştir.

\section{Çalışma Grubu ve Materyali}

Çalışma grubu,e-posta yazımı ve kullanımı konusunda görüşleri alınan 24 öğrencidenoluşmaktadır. Çalışma materyali ise, bir vakıf üniversitesinin farklı fakülte ve bölümlerinde okuyan birinci sınıf öğrencilerinin yazdığı 50 e-postadan meydana gelmektedir. E-postalar, 
öğrencilerin son bir yılda araştırmacıya gönderdikleri e-postalar arasından seçkisiz yöntemle belirlenmiştir. Görüşmeler, gönüllü öğrencilerle gerçekleştirilmiştir. Çalışma grubunu oluşturan katılımcılarla çalışma materyalinin toplandığı katılımcılar farklı öğrencilerdir.

\section{Verilerin Toplanması}

Veriler, E-Posta Yazma Yeterliliği Envanteri ve yapılandırımış görüşme formu ile toplanmıştır. Öğrencilerinson bir yıl içinde gönderdikleri elektronik posta metinleri, veri havuzu olarak kabul edilmiştir. Bu veri havuzunun içinden seçkisiz yöntemle alınan 50 e-posta, E-Posta Yazma Yeterliliği Envanteri ile analiz edilmiştir.Verilerintoplanması sürecinde öğrencilere herhangi bir müdahalede bulunulmamış, e-postalar,öğrenciler tarafından, eğitim öğretimin doğal akışı içinde gönderilmiştir.

Seçilen e-postaların toplanması ve analizi için kullanılanenvanteraraştırmacılar tarafından geliştirilmiştir. Geliştirilme sürecinde, ilgili literatür gözden geçirilmiş, e-posta yazarken dikkat edilmesi gereken kuralları ortaya koyan herhangi bir çalışmaya rastlanmamıştır. Öğrenciler tarafından yazılan e-postaların hangi çerçeveye göre incelenmesi gerektiği konusunda kritikler yapılmış, bilgisayar ve teknoloji uzmanı bir kişinin görüşlerininde alınması neticesinde, 10 maddelik bir envanter ortaya konmuştur. Öğrencilerin e-postaları arasından seçilen 50 e-postanın sınıflaması bu envanter çerçevesinde gerçekleştirilmiştir.

Çalışmada kullanılan diğer veri toplama aracı 3 soruluk yapılandırılmış görüşme formudur. Yapılandırılmış görüşme formunun oluşturulma sürecine iki araştırmacı ve bir uzmankatkıda bulunmuştur.

\section{Verilerin Analizi}

Veriler, araştırmacılar tarafından geliştirilen E-Posta Yazma Yeterliliği Envanteri(Tablo 1) kullanılarak çözümlenmiştir. Envanter aracılı̆̆ıyla 50 e-posta; "adres, konu, selamlama, yazım ve noktalama, dil kullanımı, yazı tipi ve punto, öncelik, cc ve bcc, açıklama, ek dosya" nitelikleri bakımından analiz edilmiştir.

Tablo 1.E-Posta Yazma Yeterliliği Envanteri

\begin{tabular}{lll}
\hline & E-PostaUnsurları & Unsurların Taşıması Gereken Nitelikler \\
\hline 1 & E-posta adresi & Kişinin adını yansıtan e-posta hesabı tercih edilmelidir. \\
\hline 2 & Konu & Her e-postada konu başlı̆̆ılmalıdır. \\
\hline 3 & Selamlama & $\begin{array}{l}\text { E-postaya selamlama ile başlanılması, e-postanın iyi dileklerle bitirilmesi } \\
\text { gerekir. Hitap kalıpları muhataba uygun seçilmelidir. }\end{array}$ \\
\hline 5 & Yazım ve noktalama & $\begin{array}{l}\text { E-posta yazarkenyazım kurallarına uyulması, noktalama işaretlerinin yerinde } \\
\text { kullanılması gerekir. }\end{array}$ \\
\hline 6 & Yil kullanımı & $\begin{array}{l}\text { Dilgünlük konuşma kalıplarından arındırılmalıdır. E-postalarda duyguların } \\
\text { ifadesi amacıyla emoji kullanılmamalıdır. }\end{array}$ \\
\hline
\end{tabular}




\begin{tabular}{lll}
\hline 7 & Öncelik & Sadece önemli e-postalara bayrak işareti konması \\
\hline 8 & Cc ve bcc & $\begin{array}{l}\text { Cc ve Bcc seçeneklerinin bilinçli kullanılması gerekir. Toplu e-posta } \\
\text { gönderimlerinde, gönderilen kişilerin birbirlerinden haberdar olması } \\
\text { isteniyorsa cc, istenmiyorsa bcc yapılarak gönderilmelidir. }\end{array}$ \\
\hline 9 & Açıklama & Eki olup, herhangi bir açıklaması olmayan e-postalar gönderilmemelidir. \\
\hline 10 & Ek dosya & ilgili ek dosyalar yüklenmeli, e-posta eksiz gönderilmemelidir. \\
\hline
\end{tabular}

Tablo 1'de, e-posta unsurları ve bu unsurların taşıması gereken nitelikler belirtilmiştir. Yazı tipi ve puntonun değerlendirilmesinde, 2 Şubat 2015 tarihinde Resmi Gazete'de yayımlanan 29255 sayılı "Resmî Yazışmalarda Uygulanacak Usul Ve Esaslar Hakkında Yönetmelik" (URL 4) göz önüne alınmıştır.

Ayrıca çalışmada, 24 öğrencinin e-posta yazmayla ilgili görüşleri çözümlenmiştir. Öğrencilerin görüşleri 3 sorudan oluşan yapılandırımış görüşme formu ile alınmıştır. Görüşme formunda öğrencilere aşağıdaki sorular sorulmuştur:

1) Elektronik posta yazarken nelere dikkat ediyorsunuz?

2) Elektronik postayı hangi amaçla kullanıyorsunuz?

3) Elektronik posta yazarken karşılaştığınız sorunlar nelerdir?

Bu sorular kapsamında alınan cevaplar içerik analizi ile çözümlenerek ifade edilen görüşlerin sıklık ve yüzdeleri tablolara aktarılmıştır.

\section{Bulgular}

Bulgular kısmında öncelikle 50 e-postanın çözümlenmesiyle elde edilen sonuçlar verilmiş, ardından 24 öğrencinin e-posta yazma konusundaki görüşlerine dair tablolar ortaya konmuştur.

Tablo 2. Öğrenci E-Postalarının Analizi

\begin{tabular}{|c|c|c|c|}
\hline & Öğrenci E-Postalarının Analizi & $\mathbf{f}$ & $\%$ \\
\hline 1 & Açıklamalı e-posta gönderen öğrenciler & 48 & 96 \\
\hline 2 & Dil kullanımına özen gösteren öğrenciler & 38 & 76 \\
\hline 3 & Adını soyadını yansıtan e-posta hesabı kullanan öğrenciler & 25 & 50 \\
\hline 4 & E-postalarına konu başlığı yazan öğrenciler & 20 & 40 \\
\hline 5 & E-postasını selamlama ile başlayıp iyi dileklerle bitiren öğrenciler & 19 & 38 \\
\hline 6 & Uygun yazı tipi ve punto ile yazan öğrenciler & 15 & 30 \\
\hline 7 & Yazım ve noktalama kurallarına dikkat eden öğrenciler & 12 & 24 \\
\hline 8 & Öncelikli e-postalara bayrak işareti koyan öğrenciler & 2 & 4 \\
\hline 9 & Ekli e-posta gönderen öğrenciler & 2 & 4 \\
\hline 10 & Cc ve Bcc seçeneklerini kullanan öğrenciler & 0 & $\mathbf{0}$ \\
\hline
\end{tabular}

Tablo 2'ye göre, öğrenciler en fazla, açıklamalı e-posta gönderme konusuna dikkat etmişlerdir $(\mathrm{f}=48)$. Bunu,e-posta yazarken dil kullanımına özen gösterme $(\mathrm{f}=38)$ ve adını soyadını yansıtan bir e- 
posta hesabı kullanma ( $f=25$ ) takip etmiştir. Öğrenci e-postalarının en az frekansa sahip unsurları ise, öncelikli e-postalara bayrak işareti koyma $(f=2)$, ekli e-posta gönderme $(f=2)$ ve cc ve bcc seçeneklerini kullanma $(\mathrm{f}=0)$ başlıklarından oluşmaktadır. Bayrak işareti koyma, ekli e-posta gönderme,cc ve bcc seçeneklerini kullanma, daha az bilinen ve kullanılan e-posta unsurları arasında yer almaktadır. Öğrencilerin bu unsurları az kullanmalarında bu neden etkili olmuş olabilir.

Tablo 3.Öğrenci Görüşlerinin Sorulara Göre Dağılımı

\begin{tabular}{|c|c|c|c|c|}
\hline & 1.Soru & 2.Soru & 3.Soru & Toplam \\
\hline & $f$ & $f$ & $f$ & $f$ \\
\hline Öğrenci Görüşleri $(\Sigma)$ & 47 & 51 & 37 & 135 \\
\hline Öğrenci Görüşleri $(\bar{X})$ & 1,96 & 2,13 & 1,54 & 5,63 \\
\hline
\end{tabular}

Tablo 3'te görüleceği üzere, öğrenciler 1.soru için 47, 2.soru için 51 ve 3. soru için 37 görüş beyan etmişlerdir. Ortalama görüş sayıları ise 1.soru için 1,96 2.soru için 2,13 ve 3.soru için 1,54'tür.

Tablo 4.Öğrencilerin E-Posta Yazarken Dikkat Edilen Hususlar

\begin{tabular}{|c|c|c|c|c|}
\hline \multirow{15}{*}{$\begin{array}{l}\text { Soru } 1 \\
\text { Elektronik posta } \\
\text { yazarken nelere } \\
\text { dikkat edersiniz? }\end{array}$} & Unsurlar & Öğrenciler (n=24) & f & $\%$ \\
\hline & Kime göndereceğimi belirlerim. & $\begin{array}{l}4,5,6,11,12,13,14 \\
15,21,22,24\end{array}$ & 11 & 46 \\
\hline & Yazım ve noktalamaya dikkat ederim. & $\begin{array}{l}2,9,10,11,12,13 \\
15,19,21,23\end{array}$ & 10 & 42 \\
\hline & Dili düzgün kullanırım. & $3,7,9,15,16$ & 5 & 21 \\
\hline & Konuyu açık ve anlaşılır yazarım. & $1,8,10,11,17$ & 5 & 21 \\
\hline & Kullandığım üsluba dikkat ederim. & $3,4,19$ & 3 & 13 \\
\hline & Yazı düzenine özen gösteririm. & $3,7,8$ & 3 & 13 \\
\hline & Hitap/selam cümlesiyle başlarım. & $17,18,20$ & 3 & 13 \\
\hline & Konu başlığını yazarım. & 11,17 & 2 & 8 \\
\hline & E-postanın gidip gitmediğini kontrol ederim. & 6 & 1 & 4 \\
\hline & @ işaretini koymaya dikkat ederim. & 13 & 1 & 4 \\
\hline & Dosyanın yüklenip yüklenmediğini kontrol ederim. & 11 & 1 & 4 \\
\hline & İçeriğin konuyla ilgili olmasına özen gösteririm. & 4 & 1 & 4 \\
\hline & E-postayı iyi dileklerle bitiririm. & 19 & 1 & 4 \\
\hline & Toplam & & 47 & 100 \\
\hline
\end{tabular}

Tablo 4 gözden geçirildiğinde, öğrencilerin e-posta yazarken en fazla dikkat ettikleri unsurların başında, e-postayı kime göndereceğini belirlemek ( $f=11)$ ve yazım ve noktalamaya dikkat etmek ( $f=10$ ) gelmektedir. Bu konuda en az görüş sunulan unsurlar ise e-postanın gidip gitmediğini kontrol etmek ( $f=1)$, @ işaretini koymak ( $f=1)$, dosyanın yüklenip yüklenmediğini kontrol etmek $(f=1)$, içeriğin konuyla ilgili olmasına özen göstermek $(f=1)$ ve e-postayı iyi dileklerle bitirmek $(f=1)$ şeklindedir. 
Tablo 5. Öğrencilerin E-Posta Kullanma Amaçları

Soru 2

Elektronik postayı hangi amaçla kullanıyorsunuz?

\begin{tabular}{llrr} 
Unsurlar & Öğrenciler $(\mathbf{n}=\mathbf{2 4})$ & $\mathbf{f}$ & $\mathbf{\%}$ \\
\hline \multirow{2}{*}{ Iletişim kurma } & $1,3,7,9,12,13,15,16$, & 13 & 54 \\
\hline Dosya paylaşma & $18,19,21,23,24$ & 7 & 29 \\
\hline Ödev gönderme & $4,5,8,11,12,14,17$ & 7 & 29 \\
\hline Hocalara soru sorma & $6,7,8,10,11,14,21$ & 5 & 21 \\
\hline Resmîkurumlarla yazışma & $9,10,11,19,20$ & 4 & 17 \\
\hline Not paylaşma & $3,4,5,11$ & 4 & 17 \\
\hline Alışverişlerde & $6,9,15,23$ & 4 & 17 \\
\hline Bilgi aktarımı & $7,8,9,21$ & 3 & 13 \\
\hline Fotoğraf ve video paylaşma & $13,18,24$ & 3 & 13 \\
\hline Belge kaydetme & $2,3,5$ & 1 & 4 \\
\hline Toplam & 8 & $\mathbf{5 1}$ & $\mathbf{1 0 0}$ \\
\hline
\end{tabular}

Yukarıdaki tablo incelendiğinde, öğrencilerin e-postayı en çok iletişim kurma ( $f=13)$, dosya paylaşma ( $f=7$ ) ve ödev gönderme $(f=7)$ amacıyla, en az ise belge kaydetme $(f=1)$, bilgi aktarımı $(f=3)$ ve fotoğraf ve video paylaşımı $(\mathrm{f}=3$ ) için kullandıkları görülmektedir.

Tablo 6. Öğrencilerin E-Posta Yazarken Karşılaştıkları Sorunlar

Soru 3

Elektronik posta yazarken karşılaştığınız sorunlar nelerdir?

\begin{tabular}{llrr} 
Unsurlar & Öğrenciler $\mathbf{( n = 2 4 )}$ & $\mathbf{f}$ & $\mathbf{\%}$ \\
\hline Belgenin zamanında ulaşmaması & $1,2,3,4,5,22,24$ & 7 & 29 \\
\hline Dosya boyutunun fazla gelmesi & $1,4,6,8,12$ & 5 & 21 \\
\hline İnternet kesintisi & $2,3,7,18$ & 4 & 17 \\
\hline Internetin yavaşlaması & $6,7,11$ & 3 & 13 \\
\hline E-postanın eksik gitmesi & 2,3 & 2 & 8 \\
\hline $\begin{array}{l}\text { Adres doğru olmasına rağmen } \\
\text { postanın gitmemesi }\end{array}$ & 14,19 & 2 & 8 \\
\hline Dosya yüklemenin zaman alması & 6 & 1 & 4 \\
\hline $\begin{array}{l}\text { Bazı posta programlarının yüksek } \\
\text { boyutlu dosya yüklemeyi }\end{array}$ & 6 & 1 & 4 \\
desteklememesi & 16 & 1 & 4 \\
\hline $\begin{array}{l}\text { E-postanın ulaştığına dair dönüt } \\
\text { olmaması }\end{array}$ & 7 & 1 & 4 \\
\hline $\begin{array}{l}\text { E-postaya gelen gereksiz postalar } \\
\text { Girişte kullanıcı adı yazarken }\end{array}$ & 24 & 1 & 4 \\
\hline E-postanın yanlış adrese gitmesi & 10 & 1 & 4 \\
\hline Yabancı sözcüklerin yazımı & 13 & 1 & 4 \\
\hline Genellikle sorun yaşamıyorum. & $9,11,15,16,17,20,21$ & 7 & 29 \\
\hline Toplam & & $\mathbf{3 7}$ & $\mathbf{1 0 0}$ \\
\hline
\end{tabular}

Tablo 6'da görüldüğü üzere, öğrencilerin e-posta yazarken karşılaştıkları sorunların başında sırasıyla belgenin zamanında ulaşmaması $(f=7)$, dosya boyutunun fazla gelmesi $(f=5)$ ve internet kesintisi $(f=4)$ gelmektedir. En az sorun ise dosya yüklemenin zaman alması $(f=1)$, e-postaya gelen gereksiz postalar $(\mathrm{f}=1)$ ve e-postanın yanlış adrese gitmesi $(\mathrm{f}=1)$ gibi konularda yaşanmaktadır. Bunun yanı sıra, sorun yaşamadıklarını ifade edenlerin sayısı 7'dir. 


\section{Sonuç}

50 e-postanın analizi sonrası ortaya çıkan sonuçlar şu şekildedir:

Öğrenciler, en fazla açıklamalı e-posta gönderme konusuna dikkat etmiştir ( $f=48$ ), bunu sırasıyla e-posta yazarken dil kullanımına özen gösterme ( $f=38$ ) ve adını soyadını yansıtan bir e-posta hesaba sahip olma $(f=25)$ takip etmiştir. Eksiz veya açıklamasız e-postalar boş e-postalardır. Bazen hem ekin gönderilmediği hem de açıklamanın yazılmadığı e-postalar da gönderilmektedir. Bu konuda daha temkinli davranılması, e-posta ekliyse dosya ve açıklamasının eklenmesi, eksiz bir e-posta ise açıklamasının tam yapılıp yapılmadığının kontrol edilmesi gerekir. Çünkü e-posta yoluyla gönderilen dosyalar genellikle açıklamaya muhtaçtır ve ilk başta anlaşılamayabilirler. Bir diğer husus da adını soyadını yansıtan bir e-posta hesabına sahip olmaktır. Her ne kadar literatürde e-posta hesabının sahip olması gereken niteliklerle ilgili bir çalışmaya rastlanmasa da e-posta hesabının tıpkı imza gibi kişiyi temsil etmesi beklenir. E-posta hesabı, mümkünse isim ve soy ismi barındırmalıdır; bu mümkün değilse, ismin baş harfi ve soy isimden oluşan hesap adı tercih edilebilir. İstenilen e-posta hesabının bir başkası tarafından alınmış olması durumunda ise, ismin baş harfiyle soy isim arasına (.), (-), (_) gibi işaretlerden biri konulabilir.

Çalışmamızda öğrencilerin e-posta yazarken en az kullandıkları unsurlar; önemli e-postalara bayrak işareti koyma $(f=2)$, ekli e-posta gönderme $(f=2)$ ve cc ve bcc seçeneklerini kullanma $(f=0)$ başıklarından oluşmaktadır. Bu sonuç, çoğu öğrencinin e-posta yazarken bayrak işareti koyma, ekli eposta gönderme, cc ve bcc seçeneklerini tercih etme gibi özellikleribilmedikleri veya kullanmadıklarını ortaya koymaktadır. Bu nedenle öğrencilerin, e-posta hizmeti sunan sağlayıııların e-posta gönderme programlarında hangi özelliklerin bulunduğu konusunda bilgilendirilmesi gerekmektedir.

24 görüşün çözümlenmesiyle ortaya çıkan sonuçlar şu şekildedir:

E-posta yazarken öğrencilerin en çok e-postayı kime göndereceğini belirleme( $f=11)$ ve yazım ve noktalama $(\mathrm{f}=10)$ konusunadikkat ettikleri tespit edilmiştir. Bu konuda en az görüş sunulan unsurların ise e-postanın gidip gitmediğini kontrol etme ( $f=1)$, @ işaretini (kuyruklu a) koyma ( $f=1)$, dosyanın yüklenip yüklenmediğini kontrol etme $(f=1)$, içeriğin konuyla ilgili olmasına özen gösterme $(f=1)$ ve e-postayı iyi dileklerle bitirme $(f=1)$ şeklinde sıralandığı belirlenmiştir.Çalışmamızda her ne kadar öğrencilerin, e-postayı kime göndereceğini belirleme ve yazım ve noktalama konularına dikkat ettikleri belirlenmiş olsa da, 24 öğrencinin görüş bildirdiği göz önüne alındığında bu sayının yetersiz olduğu göze çarpmaktadır. Bu sonuç, az frekansa sahip diğer unsurlarla birlikte düşünüldüğünde, öğrencilerin e-posta yazarken nelere dikkat edeceklerini tam olarak bilmediklerini göstermektedir. 
Çalışmamızda öğrencilerin e-postayı en çok iletişim kurma ( $f=13)$, dosya paylaşma $(f=7)$ ve ödev gönderme ( $f=7$ ) amacıyla kullandıkları; en az ise belge kaydetme ( $f=1)$, bilgi aktarımı $(f=3)$ ve fotoğraf ve video paylaşımı $(f=3)$ için tercih ettikleri saptanmıştır. Öğrencilerin e-posta kullanma gerekçelerinin en fazla iletişim üzerinde yoğunlaştığı görülmektedir. Öğrencilerin e-posta oluşturma süreci konusunda bilinçlendirilmesi,onlarda farkındalık yaratarak e-postayı kullanma amaçlarının çeşitlenmesini sağlayacaktır.

Öğrenci görüşlerinden elde edilen sonuçlara göre e-posta yazma sürecinde karşılaşılan sorunların başında belgenin zamanında ulaşmaması $(f=7)$, dosya boyutunun fazla gelmesi $(f=5)$ ve internet kesintisi $(f=4)$ gelmektedir. En az sorun belirtilen durumlar ise dosya yüklemenin zaman alması ( $f=1)$, e-postaya gelen gereksiz postalar $(f=1)$ ve e-postanın yanlış adrese gitmesi $(f=1)$ gibi konulardır. Bunun yanı sıra, e-posta yazarken genellikle sorun yaşamadıklarını ifade edenlerin sayısının 7 olduğu tespit edilmiştir. Çalışmamızda, sorun yaşadığını ifade eden öğrencilerin azımsanmayacak kadar fazla olduğu görülmektedir. Öğrencilere e-postanın ne olduğu, hangi amaçla yazıldığı ve en önemlisi nasıl yazıldığı konusunda eğitim verilmesi gerekmektedir. Nitekim yapılan bir çalışmada, öğretmenleri tarafından arka plan bilgisi sağlanan öğrencilerin e-posta yazma becerilerinin önemli ölçüde geliştiğinin (Nazari ve Niknejad, 2015) saptanmış olması, öğrencilerin e-posta yazmayı kendi kendilerine değil, bu konuda uzmanlaşmış olan bir öğreticiden destek alarak öğrenmelerini gerektiğini göstermektedir.

\section{Öneriler}

Çalışmamızda e-posta yazma sürecinin hangi unsurlar çerçevesinde gerçekleştiği ortaya konmaya çalışıımıştır. Literatürde e-posta iletişiminin nasıl olması gerektiğine dair bir çalışmaya rastlanmamış olması, öğrencilerin e-posta yazmayı tam olarak bilememelerinin bir gerekçesini oluşturabilir. Bu nedenle,e-posta iletişiminin; ne olduğuna, hangi unsurlardan oluştuğuna, ne tür imkânlar ve yararlar sağladığına dair ayrıntılı çalışmalara ihtiyaç vardır.

Teknolojinin gelişmesiyle birlikte iletişim konusunda ciddî mesafeler alınmıştır. Öyle ki iletişim daha hızlı bir şekilde kurulabilmekte, belge, resim, müzik, video gibi dosyalar internet üzerinden kolaylıkla alınıp gönderilebilmektedir. Öğretmen adaylarınınbu teknolojik gelişmelere ayak uydurarak e-posta iletişimini iyi öğrenmesi beklenmektedir. Çalışmamız üniversite öğrencilerinin e-posta yazma ve gönderme konusunda daha fazla bilgilendirilmesi gerektiğini ortaya koymaktadır. Bu nedenle özellikle birinci sınıfta verilen yazılı anlatım derslerinde, e-posta türünün öğretilmesine özen gösterilmeli, öğrencilere uygulamalı çalışmalar yaptırılmalıdır. 
Bu çalışmada farklı fakültelerde okuyan üniversite birinci sınıf öğrencileri ile çalışımıştır. Bu alanda fakültelertemel alınarak ayrı ayrı çalışmalar gerçekleştirilebilir. Ayrıca öğrencilerin e-posta yazma becerileri farklı sınıf seviyeleri dikkate alınarak da incelenebilir.

\section{Kaynaklar}

Aslan, A. (2016). Türkiye'de çocukların güvenli internet kullanımında 2010-2015 yılları arasındaki değişimler ve uygulamaların yansımaları.Erzurum: Atatürk Üniversitesi, Yayımlanmamış Doktora Tezi.

Baron, N. S. (1998). Lettersbyphoneorspeechbyothermeans: Thelinguistics of email. Language \&Communication, 18(2), 133-170.

Bayır, E. A. (2014). Çevrimiçi öğrenme ortamlarında sohbet ve e-posta kullanımının öğrencilerin işlemsel uzaklık algılarına etkisi. Ankara: Gazi Üniversitesi, Yayımlanmamış Doktora Tezi.

Bengshir, T. K. (2000). Devlet-vatandaş iletişiminde e-posta. Amme Idaresi Dergisi, 33(4), 49-61.

Bradley, T. \&Carvey, H. (2006). Essential computer security: everyone's guide to email, internet, and wireless security. Canada: Syngress Publishing.

Chen, C. F. E. (2006). Thedevelopment of e-mail literacy: Fromwritingtopeerstowritingtoauthorityfigures.Language Learning \&Technology, 10(2),35-55.

Çakır, H. ve Topçu, H. (2006). Bir iletişim dili olarak internet. Erciyes Üniversitesi Sosyal Bilimler Enstitüsü Dergisi, 19(2), 71-96.

Dabbagh, N., \&Bannan-Ritland, B. (2005). Online learning: Concepts, strategies, and application. Upper Saddle River, NJ: Pearson Education, Inc.

Eliçin, C. (2011). Thestrategies in requestsandapologies of Turkishfledstudents: A comparison of electronicmailsand DCT data. Unpublished Master Thesis. Boğaziçi UniversitySocialSciencelnstitute, İstanbul.

Erkan, D. Y. (2004). Efficact of cross-cultural e-mail exchangeforenhancing EFL writing: A perspectivefortertiarylevelTurkish EFL learners. Adana: Çukurova Teknik University, Unpublished Doctorate Thesis.

Erkan, D. Y. (2013). Kültürler arası elektronik posta yolu ile yazışmanın İngilizce yazma becerisinde özyekinliğe etkisi. Çukurova Üniversitesi Sosyal Bilimler Enstitüsü Dergisi, 22(1), 25-42.

Filippone, M., \&Survinski, M. (2016). Theimportance of etiquette in schoolemail. AmericanSecondaryEducation, 45(1), 22-27.

Güler, C. (2007). Uzaktan öğrenenlerin e-postayla etkileşime girme sıklılarıyla yüz yüze ortamlarda iletişime girme isteklilikleri arasındaki ilişki.Eskişehir: Anadolu Üniversitesi,Yayımlanmamış Yüksek Lisans Tezi.

Gürkaya, B. D. (1999). Using the internet andelectronic mail in writingclasses: A study on thereactionsandsuccess of preparatorystudents at lşık University. Ankara: Orta Doğu Teknik University, Unpublished Master Thesis.

Hani, N. A. B., \&Alghonaim, A. S. (2014). Theutilization of e-mail technology in developingwritingskillstofreshman EFL learners. InstructionalTechnology, 11(8), 43-53.

Haşıloğlu, S. B. (1999). Elektronik ticaret ve stratejileri. İstanbul: Türkmen Kitabevi.

Huang, E. Y. \& Lin, S. W. (2014). How does e-mail useaffectperceivedcontrol of time? Information \& Management, 51(6), 679-687.

Lamb, S. E. (2006). Office e-mailsandvoicemessaging. Business \&EconomicReview, October-December, 30-31.

MEB. (2017). Bilişim teknolojileri ve yazılım dersi öğretim programı (Ortaokul 5 ve 6. sınıflar). Ankara: Millî Eğitim Bakanlığı.

Munter, M., Rogers, P. S., \&Rymer, J. (2003). Business e-mail: Guidelinesforusers. Business CommunicationQuarterly, 66(1), 26-40. 
Nawaz, W., Khan, K. U., \& Lee, Y. K. (2016). A multi-userperspectiveforpersonalizedemailcommunities. ExpertSystemswith Applications, 54, 265-283.

Nazari, B., \&Niknejad, S. (2015). E-mail Writing: Providing Background Information in theCore of ComputerAssistedInstruction. Turkish Online Journal of DistanceEducation, 16(1), 193-211.

Özbay, S. ve Akyazı, S. (2004). Elektronik ticaret. Ankara: Detay Yayıncılık.

Shang, H. F. (2007). An exploratory study of e-mail application on FL writing performance. Computer Assisted Language Learning, 20(1), 79-96.

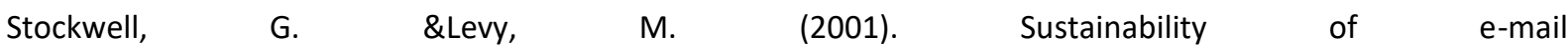
interactionsbetweennativespeakersandnonnativespeakers, ComputerAssisted Language Learning, 14(5), 419-442.

Türk Dil Kurumu. (2011). Türkçe sözlük(11. Baskı). Ankara: Türk Dil Kurumu Yayınları.

URL 1: https://wearesocial.com/special-reports/digital-in-2017-global-overview (Erişim Tarihi: 15.03.2017).

URL 2: https://ttkb.meb.gov.tr/www/ogretim-programlari/icerik/72 (Erişim Tarihi: 18.06.2017).

URL 3: http://mufredat.meb.gov.tr/ProgramDetay.aspx?PID=152 (Erişim Tarihi: 20.08.2017).

URL 4: http://www.resmigazete.gov.tr/default.aspx (Erişim Tarihi: 07.10.2017).

Zarepour, F., \&Saidloo, M. I. (2016). An analysis of Iranian EFL learners' English written requestive e-mails. Journal of Language Teaching and Research, 7(3), 579-585. 